\title{
ASSESSMENT OF LAND-COVER CHANGES AND CARBON SEQUESTRATION POTENTIALS OF TREE SPECIES IN J4 SECTION OF OMO FOREST RESERVE, OGUN STATE, NIGERIA
}

\author{
*Adeyemi, A. A. and Adeleke, S. O. \\ Department of Forest Resources Management, University of Ilorin, Ilorin, Nigeria \\ *Corresponding author's email: adeyemi.aa@unilorin.edu.ng or adeyemiadesoji@yahoo.com; Tel.: +2348032082627 \\ (Received: 13 ${ }^{\text {th }}$ October, 2019; Accepted: 31 ${ }^{\text {st }}$ March, 2020)
}

\section{ABSTRACT}

\begin{abstract}
We evaluated carbon stock accumulation on potential of tree species in five forest-types in Omo Forest Reserve of western Nigeria. This included four forest plantations and a natural forest of mixed species. The reserve was stratified into Gmelina arborea, Tectona grandis, Pinus carebeae and Nauclea diderrichii plantations as well as natural forest. Each forest-type was assessed using circular plot method. Plot points were pre-determined using remote sensing. For each point, two circular plots were established, the main plot with a radius of $12.61 \mathrm{~m}$ (500 $\left.\mathrm{m}^{2}\right)$ and the subplot with a radius of $5.64 \mathrm{~m}\left(100 \mathrm{~m}^{2}\right)$. In each plot, tree Dbh and height were measured for trees with $\mathrm{Dbh} \geqslant 10 \mathrm{~cm}$, while only trees with $\mathrm{Dbh}<10 \mathrm{~cm}$ but $>2 \mathrm{~cm}$ (i.e. $2 \mathrm{~cm} \leqslant \mathrm{Dbh}<10 \mathrm{~cm}$ ) were considered in the sub-plot. Soil samples were also collected at 10 locations with 2 each in the north, south, east, west and at the plot centre, in each forest-type. The samples were analysed to obtain soil organic carbon. Above- and belowground biomass and carbon stocks were estimated using the appropriate allometries formulated for the tropics. All empirical relationships were included in the existing allometries with Dbh and height as predictors. Landsat images of the reserve in 1991, 2000, 2014 and 2019 were processed and analysed to assess forest degradation. The results revealed that 23 -year-old Pinus caribaea plantation sequestered more carbon $(35.78 \pm 2.73$ tons $/$ ha $)$

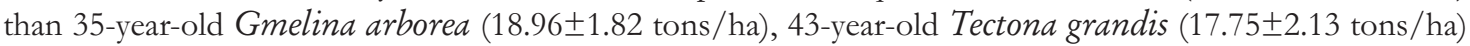
and 43-year-old Nauclea diderrichii (17.36 \pm 1.87 tons/ha) plantations and natural forest (21.98 22.38 tons/ha). The study showed that stand density influences carbon stock accumulation of forest. It was observed that individual stems of Pinus caribaea were better carbon accumulators than Gmelina arborea, Tectona gransdis and Nauclea diderrichii. The same trend was observed for $\mathrm{CO}_{2}$ captures as Pinus caribaea captured $131.31 \pm 10.02$ tons / ha with Nauclea diderrichii the least, having a value of $63.71 \pm 6.9$ tons $/ \mathrm{ha}$.
\end{abstract}

Keywords: Biomass, Carbon stock, Degradation, Forest-type, Stand density

\section{INTRODUCTION}

According to Ostadhashemi et al. (2014), the world's forests stored an estimate of 289 Gt of carbon in their biomass. However, this value has previously been reported to shrink by $0.5 \mathrm{Gt}$ annually in five years, between 2005 and 2010 due, largely, to forest disappearance (FAO, 2010). In the context of climate change, special attention is given to carbon, which is seen as a major constituent of greenhouse gas emissions (Liu et al., 2014). Forests account for $48 \%$ of the total storage capacity of carbon by global terrestrial ecosystems (Watson et al., 2000; IPCC, 2001). Trees, the major components of forest, absorb large amounts of atmospheric carbon dioxide $\left(\mathrm{CO}_{2}\right)$ through photosynthesis, and forests return an almost equal amount to the atmosphere by auto- and heterotrophic respirations (Folega et al., 2010).
The main carbon pool in tropical forest ecosystems consists of the living biomass of trees, understorey vegetation, dead mass of litter, woody debris and soil organic matter (Kumar and Sharma, 2015). Kumar and Sharma (2015) observed that carbon stored in the AboveGround Biomass (AGB) of trees is the largest pool. Quantifying AGB and Below-Ground Biomass (BGB) carbon is a critical step in estimating carbon stocks and fluxes from tropical forests. The major environmental concern today is the increase of carbon dioxide in the atmosphere and its potential effect on climate, considered as global warming. However, a small fraction of carbon remaining in forests continuously accumulates in vegetation, detritus, and soil. Thus, undisturbed forest ecosystems have been viewed as important global carbon sinks (Lorenz and Lal, 2009). 
Forests remain a reservoir of carbon (FAO, 2003; 2008) due to their good capacity to store carbon from the atmosphere (Ullah and Amin, 2012). However, in the face of current anthropogenic activities and relentless efforts by people to survive, lots of forests have been lost, especially in the tropics. To that end, afforestation and enrichment planting have long been suggested as viable options in addressing high rates of forest losses in order to boost carbon base or reservoir. Photosynthesis in plants converts carbon dioxide $\left(\mathrm{CO}_{2}\right)$ to biomass, thereby reducing the carbon in the atmosphere and stores it in plant tissues, above and below ground (Ahmedin et al., 2013). The biomass produced is mainly stored as AGB, BGB, dead wood, litter and soil organic matter in the forest ecosystem (Cienciala et al., 2010).

Forest ecosystems are very important in the global carbon cycle as they sequester close to $80 \%$ and $40 \%$ of all above- and below-ground terrestrial organic carbon, respectively (IPCC, 2001), and they are directly influenced by deforestation and forest degradation (Gibbs et al., 2010). According to Vashum and Jayakumar (2012), Haghparast et al. (2013), carbon sequestration could reduce $\mathrm{CO}_{2}$ emission by up to $55 \%$ by 2100 , and this would have great influence on greenhouse gas contribution to climate pattern of the world. Quantification of carbon stock potential of any ecosystem is challenging, however, it is crucial for sustainability and for making decision for a safe environment.

Hence, periodic evaluation of the amount of carbon stored in the forest ecosystem is a means of determining the $\mathrm{CO}_{2}$ emission due to deforestation and degradation (Vashum and Jayakumar, 2012). Information on AGB and BGB carbon in Omo Forest Reserve, one of the remaining protected areas in Nigeria is too inadequate to evolve sustainable forest management strategies. Besides, potential and adequacy of a non-destructive carbon assessment method has not been employed in the area. Although some reported anthropogenic activities in the reserve were rumoured to have diminished the extents and values of the reserve, no appreciable efforts have hitherto been made to put the causal factors in prespectives. Moreover, the impacts these may have had on biodiversity in the reserve remains unknown and also the capacity of the different forest-types in the area to sequester carbon. Therefore, we assessed total biomass carbon sequestered by the reserve to aid sustainable management practices.

\section{MATERIALS AND METHODS}

The study area was the J4 Section of Omo Forest Reserve (OFR), which is located between latitudes $6^{\circ} 35^{\prime}$ and $7^{\circ} 05^{\prime} \mathrm{N}$ and longitudes $4^{\circ} 19^{\prime}$ and $4^{\circ} 40^{\prime} \mathrm{E}$ in Ijebu East and North Local Government Areas of Ogun State in western Nigeria (Figure 1). It covers an area of about 130,500 ha, and bounded with other three important forest reserves in the west of the country. The rainy season in OFR usually commences in March with mean annual rainfall range of about 1600 to $2000 \mathrm{~mm}$ and two peaks in June and September. The temperature ranges from $32.15^{\circ} \mathrm{C}$ to $21.40{ }^{\circ} \mathrm{C}$ with a minimum relative humidity of $76.34 \%$ (Adebisi, 2004). The vegetation of the reserve is a moist semideciduous rainforest. Most of the forests are disturbed with a substantial part converted to monoculture plantations of Gmelina arborea in a programme assisted by loans from the World Bank and the African Development Bank to provide material for a pulp mill in the early 1990s. For effective management, the reserve was subdivided into four areas viz: J1, J3, J4 and J6. These sub-divisions were apportioned to enclave dwellers in isolated villages or camps. Estimated human population in the area is between 20,000 and 25,000. Farming, fishing, hunting and nontimber forest products (NTFPs) gathering are the predominant occupations for the majority of the enclaves. 


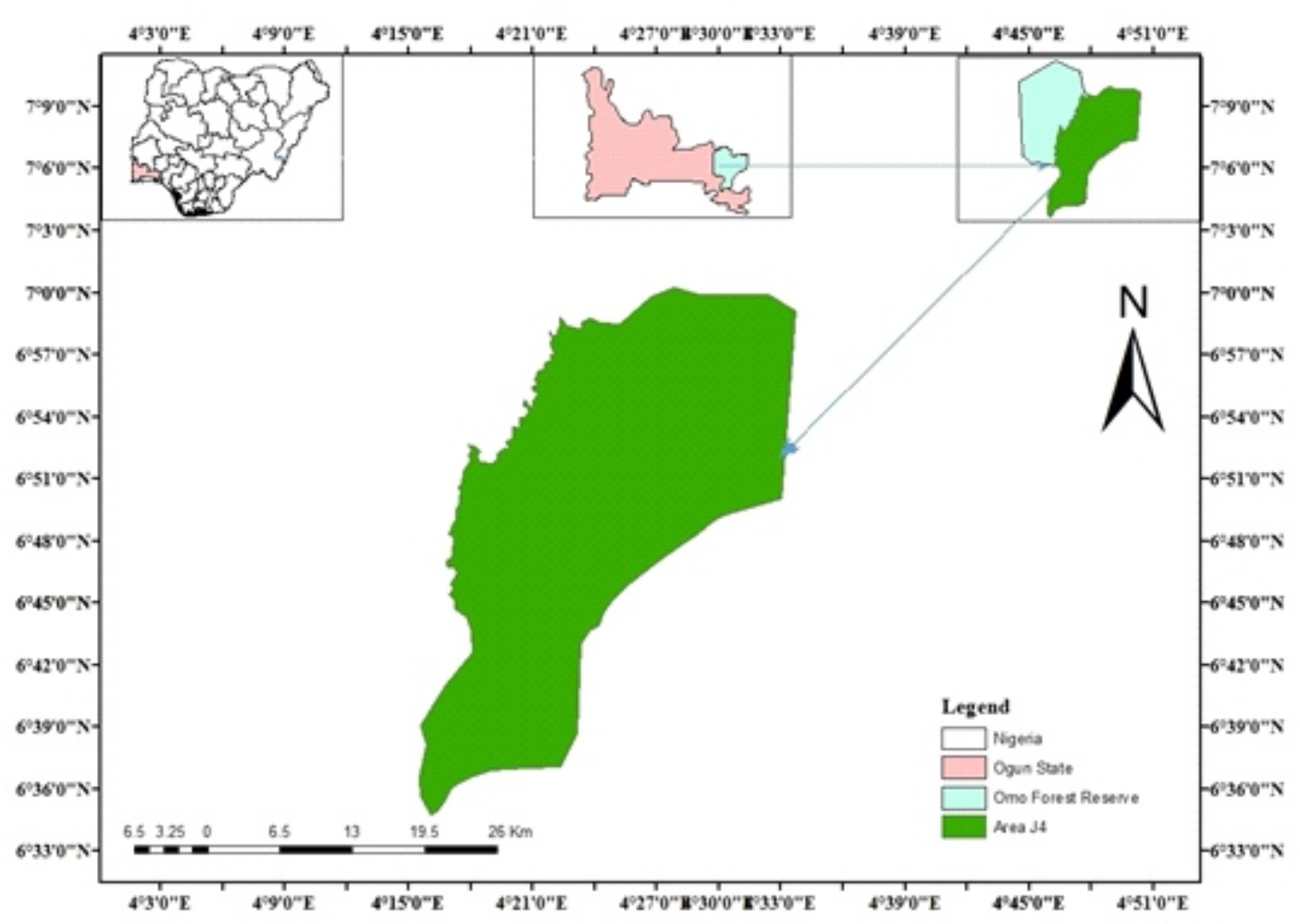

Figure 1: Map of the Study Area

With the exception of the 640 ha Strict Nature Reserve, now a Biosphere Reserve at the centre, most of the forest are disturbed with a substantial parts converted to forest plantations, especially of, but not limited to, exotic tree species such as Gmelina arborea, Tectona grandis and Pinus caribaea. The topography of the sites varies widely from nearly flat to rolling hills. About $80 \%$ of the sites are well-drained into the watershed of River Omo, which is the major river that traverses the reserve. The uneven topography is characterized by numerous small hills, which are dissected by tributaries of the Omo, Shasha and Oluwa Rivers. This unevenness has been attributed to past geological events (Ojo, 2004). The area was once composed of sedimentary rocks, probably sandstone, of varying coarseness. A period of volcanic activity in the past heated these rocks to such an extent that they became viscous and flowed.

\section{Data Collection}

For the field data, stratified random sampling technique was adopted for the study. Five foresttypes including natural forest, Gmelina arborea, Tectona grandis, Pinus carebeae and Nauclea diderrichii plantations within the reserve were distinguished. Each forest-type was assessed using circular plot method. Plot points were predetermined using remote sensing. For each point, two circular plots were established, the main plot with a radius of $12.61 \mathrm{~m}\left(500 \mathrm{~m}^{2}\right)$ and the subplot (within the main plot) with a radius of $5.64 \mathrm{~m}$ (100 $\left.\mathrm{m}^{2}\right)$. After locating each point, the centre was marked with GPS before the inventory measurements. In each plot, diameter at breast height (Dbh) and height were measured using diameter tape and Spiegel Relaskop. In the main plot, all trees with $\mathrm{Dbh} \geqslant 10 \mathrm{~cm}$ were measured while only trees with $\mathrm{Dbh}<10 \mathrm{~cm}$ but $>2 \mathrm{~cm}$ (i.e. $2 \mathrm{~cm} \leqslant \mathrm{Dbh}<10 \mathrm{~cm}$ ) were considered. To ensure accurate placement of the sample plot, GPS receiver was used to locate plot centres as situated on the map. Landsat images of 1991, 2002, 2014 and 2019 were acquired from the US Geological Survey (USGS)'s Earth Explorer. The images were processed and analyzed using iso-cluster unsupervised classification in ArcGIS 10.5, mainly to ascertain possible forest carbon pool in the area. The major dominant land-cover types within the reserve were assessed during groundtruthing to enhance image classification. The images were then reclassified into four land-cover types, viz: closed forest, degraded forest, buil-up 
area and bare land.

\section{Soil Sampling}

Soil samples were collected at 10 locations (i.e. 2 each from north, south, east, west and centre) in each of the forest-types. The samples were taken at $0-15$ and $15-30 \mathrm{~cm}$ depths since most of carbon are concentrated within 0 to $30 \mathrm{~cm}$ of soil depths. The soil samples were collected following standard practices for sample collections. A total of 300 samples were collected, air-dried and bulked into 50 composite samples for further laboratory analyses.

\section{Data Analysis}

Measured trees were grouped into diameter classes as: sapling (i.e. $5 \leqslant \mathrm{Dbh}<10 \mathrm{~cm}$ ), the pole size tree $(10-25 \mathrm{~cm})$ and the standard size trees $(\mathrm{Dbh} \geqslant 25 \mathrm{~cm})$. To estimate other tree components, biomass equations for tree species growing in the tropics were used. All empirical relationships were included in the existing allometric equations with Dbh and height as the predictors, either singly, or in combinations. Estimation of tree biomass, carbon stock, soil carbon stock were done for each of the foresttypes as given in the subsequent sections.

\section{Estimation of Biomass and Carbon Stock}

Above-ground Biomass

The above-ground biomass (AGB) for each of the forest strata were estimated from the allometric equation by Brown (1997), using field measurements of Dbh and height of individual trees that make up each stratum of the forest. The AGB for each of the forest-types was then multiplied by its extent, as follows:

$$
\begin{aligned}
& A B G_{\text {land-cover }}=\sum \exp \left\{^{-3.1141+0.9719 \mathrm{ln}}\right. \\
& \left.\left(\mathrm{Dbh} \text { land-cover } \times \mathrm{H}_{\text {land-cover }}\right)\right\}
\end{aligned}
$$

Therefore, the total AGB of each forest-type was calculated using:

$A B G_{\text {total }}=\mathrm{ABG}_{\text {forest-type }} \times$ Area of forest type (2)

Below-ground Biomass

Below-ground biomass was estimated from AGB, as developed by Ponce-Hernandez (2004) for a non-destructive approach, which depends on below-ground biomass values for vegetation as $20 \%$ of the above-ground biomass:

$$
B G B=20 \% \times A G B
$$

Where: $\mathrm{BGB}=$ below-ground biomass;

$\mathrm{AGB}=$ above-ground biomass;

exp. = exponential function;

ln = natural logarithm;

Dbh $=$ diameter at breast height .

Soil Carbon Stock

The total organic carbon (TOC) matters were determined using the Walkley-Black method (PeRie and Ouimet, 2008). Soil carbon stock was computed for each of the forest-types by multiplying the concentration of total carbon by bulk density and the corresponding depth at which the sampling was collected, as proposed by Kauffman et al. (2012), taking into account that soil carbon is concentrated between 0 and $30 \mathrm{~cm}$ depth.

$S C=b d \times s d \times \%$ Carbon

Where: $S C=$ soil carbon $(\mathrm{mg} / \mathrm{ha}) ; b d=$ bulk density $\left(\mathrm{g} / \mathrm{cm}^{3}\right) ; s d=$ soil depth $(\mathrm{cm})$.

\section{$S C_{0-15 \mathrm{~cm}}$ of forest type $=$ \\ $\sum T O C \times$ depth $\times$ bulk density}

\section{$S C_{15-30 \mathrm{~cm}}$ of forest type $=$ $\sum T O C \times$ depth $\times$ bulk density}

Total Soil Carbon $=S C_{0-15 \mathrm{~cm}}+S C_{15-30 \mathrm{~cm}(7)}$ The sum total of all the biomass obtained from the three pools (i.e. AGB, BGB and SOC) were calculated and the carbon stock was obtained using Ponce-Hernandez's (2004), as modified:

\section{Carbon stock in standing tree $=$}

Total biomass $\times \%$ Carbon

Total carbon stock $=$

$$
\begin{aligned}
& \mathrm{AG}_{\text {carbonstcok }}+\mathrm{BG}_{\text {carbon stock }} \\
& \text { Total carbon }=\mathrm{AG}_{\text {carbonstcok }}+ \\
& \mathrm{BG}_{\text {carbon stock }}+\text { Soil } \mathrm{l}_{\text {carbon }}
\end{aligned}
$$


Trendanalysis

$\Delta L C=L 2-L 1$

\section{Rate of change}

$\mathrm{R}_{\mathrm{t}}=\left((L 2-L 1) X \frac{1}{L 1 X t}\right) X 100$

Where: $=\Delta L C$ change in land cover; $\mathrm{L}_{1}(\mathrm{ha})=$ final year; $\mathrm{L}_{2}(\mathrm{ha})=$ initial year; $\mathrm{t}$ (year) $=$ periodic interval.

\section{Classification Accuracy Assessment}

The overall accuracy of land-use/land-cover classification was done by creating a confusion matrix in ArcMap 10.4 using ground reference points obtained during ground-truthing, and following these steps:

Spatial Analyst Tools Extraction Extract Multi Values to Points Input point features (input the Ground-truth GPS points collected on the field) Input raster (input the classified raster) $>$ Ok done.

The attribute table was then exported (in dBASE format) for further analysis of the confusion matrix to determine classification accuracy and Kappa Coefficient. A total of 400 ground-truthed points (locations) were used for accuracy assessment of the land-use/land-cover classification. A total of 400 points were also created in the classified image of the study area to generate the cell array for confusion matrix table. This was carried out by dividing the total correctly-classified pixels by the total number of pixels in the confusion matrix following Liu et al. (2007), Enaruvbe and Atedhor (2015), Rwanga and Ndambuki (2017). Overall classification accuracy was determined by:

$\mathrm{Y}=\frac{\sum_{i=1}^{n} x_{i}}{\sum_{j=1}^{N} X_{j}} \times 100$

Where: $Y=$ overall accuracy; $\sum_{i=1}^{n} x_{i}=$ sum of the correct points; $X j=\sum_{j=1}^{N} x_{i}=$ total number of all
points.
Other statistics used for accuracy assessment included sensitivity (producer's accuracy), specificity, commission error, omission error, users' accuracy and Kappa's coefficient $(K)$ as given in the subsequent equations.

$$
\text { Producer's Accuracy }=\frac{w}{w+x}
$$

User's Accuracy $=\frac{y}{y+z}$

Specificity $=\frac{z}{x+z}$

$$
\text { Commission Error }=1-\text { Specificity }
$$

$$
\text { Ommission Error }=1-\text { Producer's Error }
$$

Where: $\mathrm{w}=$ number of times a classification agreed with the observed value; $\mathrm{x}=$ number of times a point was classified as ' $a$ ' when it was observed to not be 'a'; $y=$ number of times a point was not classified as 'a' when it was observed to be ' $a$ '; $z=$ number of times a point was not classified as 'a' when it was not observed to be 'a'. Kappa's coefficient measures perfect agreement between prediction and reality or classification results and the real observation, as is the case in this study. It was computed as:

$\mathrm{K}=\frac{N \sum_{i=1}^{n} x_{i j}-\sum_{i j=1}^{r}\left(x_{i j}+X x_{+1}\right)}{N^{2} \sum_{i j=1}^{r}\left(x_{i j} X x_{+1}\right)}$

Where: $r=$ number of rows and columns in error matrix; $\mathrm{N}=$ total number of observations (pixels); $\mathrm{x}_{\mathrm{ij}}=$ observations in the ith row and $\mathrm{jth}$ column; $\mathrm{x}_{+1}$ $=$ marginal total of the ith row; and $x_{+1}=$ marginal total of the jth column.

Kappa Coefficient ranges between 0 and 1. A Kappa coefficient of 1 implies perfect agreement, while any value nearing zero means that the agreement between prediction and reality or between classification and real observation is no better than that due to chance. Kappa statistic is categorized as reproduced by Rwanga and Ndambuki (2017), and shown in table 1. 
Table 1: Rating Criteria for Kappa Statistics

\begin{tabular}{ccc}
\hline SN & Kappa statistic & Strength of agreement \\
\hline 1 & $<0.0$ & Poor \\
2 & $0-0.2$ & Slight \\
3 & $0.21-0.4$ & Fair \\
4 & $0.41-0.6$ & Moderate \\
5 & $0.61-0.8$ & Substantial \\
6 & $0.81-1.0$ & Almost perfect \\
\hline
\end{tabular}

Source: Rwanga and Ndambuki (2017)

\section{RESULTS}

Five forest-types including Gmelina arborea, Pinus caribeae, Nauclea diderrichii, Tectona grandis plantations and natural forest were distinguished within the reserve. Figure 2 shows the tree diameter classes within the forest-types.
Most of the trees encountered fell in the Dbh class of $10-25 \mathrm{~cm}$. In the Gmelina arborea plantation, there were 165 trees/ha in the diameter class of $<10 \mathrm{~cm}$ and 298 trees/ ha in the diameter class 10$25 \mathrm{~cm}$ with 100 trees $/$ ha in $\geqslant 25 \mathrm{~cm}$. Pinus caribaea has 491 trees/ha in 10-25 cm class with 370 trees/ha in Dbh class $>25 \mathrm{~cm}$. In Nauclea diderrichii plantation, 239 trees/ha were in the Dbh class of between 10 and $25 \mathrm{~cm}$, and 207 trees/ha in the above $25 \mathrm{~cm}$. There were 172, 212, and 186 trees/ha of Tectona grandis in the diameter classes of $<10 \mathrm{~cm}, 10-25 \mathrm{~cm}$ and $\geqslant 25$ $\mathrm{cm}$, respectively. The natural forest had only 119 , 296 and 141 trees/ha in the diameter classes of $<$ $10 \mathrm{~cm}, 10-25 \mathrm{~cm}$ and $>25 \mathrm{~cm}$, respectively.

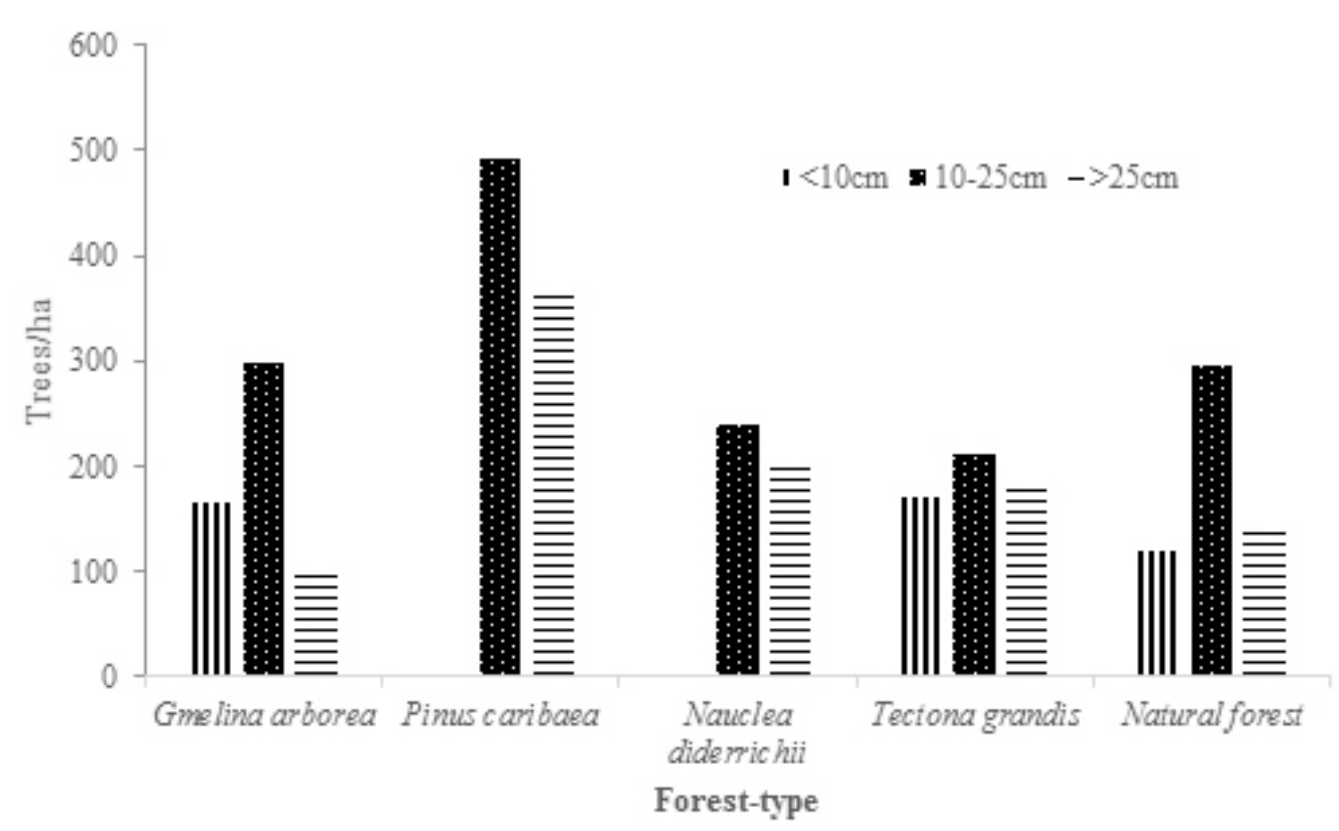

Figure 2: Tree Diameter Classes

Table 2 presents the stand-level tree growth characteristics in the study area. The mean Dbh ranged between $12.65 \pm 3.6$ and $34.59 \pm 7.9 \mathrm{~cm}$ for the five forest-types. Mean height values were between $9.0 \pm 4.0 \mathrm{~m}$ in Tectona grandis plantation and $29.75 \pm 7.5 \mathrm{~m}$ in the natural forest. In terms of stand density, Pinus caribaea was highest with 861 trees/ha and $55.73 \mathrm{~m}^{2} / \mathrm{ha}$ in basal area. Nauclea diderrichii plantation was least-densed with 446 trees/ha. 
Table 2: Stand-level Tree Growth Characteristics in J4 Omo Forest Reserve

\begin{tabular}{lcccccc}
\hline Forest type & Age $(\mathbf{y r})$ & Dbh $(\mathbf{c m})$ & Height $(\mathbf{m})$ & N/ha & BA $\left(\mathbf{m}^{2} / \mathbf{h a}\right)$ & V $\left(\mathbf{m}^{3} / \mathbf{h a}\right)$ \\
\hline Gmelina arborea & 35 & $12.65 \pm 3.6$ & $19.0 \pm 6.6$ & 563 & 51.29 & 11.80 \\
Pinus caribaea & 23 & $24.30 \pm 12.8$ & $21.1 \pm 1.8$ & 861 & 55.73 & 12.60 \\
Nauclea diderrichii & 43 & $25.27 \pm 10.1$ & $15.3 \pm 5.7$ & 446 & 18.65 & 4.24 \\
Tectona grandis & 43 & $13.05 \pm 4.6$ & $9.0 \pm 4.1$ & 570 & 50.25 & 11.79 \\
Natural forest & - & $34.59 \pm 7.9$ & $29 \pm 7.5$ & 556 & 17.50 & 4.41 \\
\hline
\end{tabular}

Abbreviations: Dbh - diameter at breast height; $\mathrm{N}$ - number of trees; $\mathrm{BA}$ - basal area; $\mathrm{V}$ - stem volume

\section{Above- and Below-ground Biomass and Carbon Stocks in J4 Section of OFR}

The above- and below-ground biomass, and carbon stocks estimated across the five foresttypes within the reserve are presented in table 3. Results revealed that Pinus caribaea has an average of $57.45 \pm 4.99$ tons/ha of above ground biomass. This was followed by the natural forest with $33.41 \pm 0.78$ tons/ha. Nauclea diderrichii was least in terms of the above-ground biomass with $27.37 \pm 2.12$ tons/ha. Similar trend was observed with respect to below-ground biomass with Pinus caribaea having the highest of $11.49 \pm$ 1.0 tons/ha and Nauclea diderrichii the least with $5.47 \pm 0.42$ tons $/$ ha. In terms of carbon stocks in the five forest-types, Pinus caribaea has $28.73 \pm$ 2.49 tons/ha and Nauclea diderrichii was least with $13.68 \pm 1.06$ tons/ha in above-ground carbon stock. The results for the below-ground carbon stock was not so different in that Pinus caribaea was highest with $5.74 \pm 0.50$ tons $/$ ha and least in Nauclea diderrichii (2.74 \pm 0.21 tons/ha). With regards to the total tree carbon stock, Pinus caribaea sequestered $34.47 \pm 2.99$ tons $/$ ha, which was the highest among the forest-types. The least values of carbon was obtained under Nauclea diderrichii plantation (16.42 \pm 1.27 tons/ha), which is not too far from what was obtained in Tectona grandis plantation. The result further revealed that Pinus caribaea significantly differed from the four other forest-types in terms of tree above- and below-ground biomass and carbon stocks (Table 3). At the individual tree level, a stem of Pinus caribaea sequestered $0.442 \pm 0.04$ ton of carbon, which was the highest among the tree species studied with least amount of carbon (0.322 \pm 0.04 ton/tree) sequestered by Tectona grandis stem (Table 4).

Table 3: Mean Separation (LSD) for Tree Biomass and Carbon Stocks in Five Forest-types

\begin{tabular}{lccccc}
\hline Forest type & $\begin{array}{c}\text { AGB } \\
\text { (tons/ha) }\end{array}$ & $\begin{array}{c}\text { BGB } \\
\text { (tons/ha) }\end{array}$ & $\begin{array}{c}\text { AGCS } \\
\text { (tons/ha) }\end{array}$ & $\begin{array}{c}\text { BGCS } \\
\text { (tons/ha) }\end{array}$ & $\begin{array}{c}\text { TTCS } \\
\text { (tons/ha) }\end{array}$ \\
\hline Gmelina arborea & $30.60 \pm 4.03^{\mathrm{a}}$ & $6.12 \pm 0.81^{\mathrm{a}}$ & $15.30 \pm 2.02^{\mathrm{a}}$ & $3.06 \pm 0.40^{\mathrm{a}}$ & $18.36 \pm 2.42^{\mathrm{a}}$ \\
Pinus caribaea & $57.45 \pm 4.99^{\mathrm{b}}$ & $11.49 \pm 1.0^{\mathrm{b}}$ & $28.73 \pm 2.49^{\mathrm{b}}$ & $5.74 \pm 0.50^{\mathrm{b}}$ & $34.47 \pm 2.99^{\mathrm{b}}$ \\
Nauclea diderrichii & $27.37 \pm 2.12^{\mathrm{a}}$ & $5.47 \pm 0.42^{\mathrm{a}}$ & $13.68 \pm 1.06^{\mathrm{a}}$ & $2.74 \pm 0.21^{\mathrm{a}}$ & $16.42 \pm 1.27^{\mathrm{a}}$ \\
Tectona grandis & $27.92 \pm 3.50^{\mathrm{a}}$ & $5.59 \pm 0.70^{\mathrm{a}}$ & $13.96 \pm 1.75^{\mathrm{a}}$ & $2.79 \pm 0.35^{\mathrm{a}}$ & $16.74 \pm 2.10^{\mathrm{a}}$ \\
Natural forest & $33.41 \pm 0.78^{\mathrm{a}}$ & $6.68 \pm 0.16^{\mathrm{a}}$ & $16.71 \pm 0.39^{\mathrm{a}}$ & $3.34 \pm 0.08^{\mathrm{a}}$ & $20.05 \pm 0.47^{\mathrm{a}}$ \\
\hline
\end{tabular}

N.B.: means with the same alphabet as superscripts under each column are not significantly different.

Abbreviations: AGB - above-ground biomass - below-ground biomass; AGCS - above-ground carbon stock; BGCS below-ground carbon stock; TTCS - total tree carbon stock 
Table 4: Average Carbon Sequestered by the Individual Stems in the Five Forest-types

\begin{tabular}{lcclc}
\hline Forest types & Age $(\mathbf{y r})$ & N/ha & TTCS (tons/ha) & MTCS (ton) \\
\hline Gmelina arborea & 35 & 563 & $18.36 \pm 2.42$ & $0.360 \pm 0.05$ \\
Pinus caribaea & 23 & 861 & $34.47 \pm 2.99$ & $0.442 \pm 0.04$ \\
Nauclea diderrichii & 43 & 446 & $16.42 \pm 1.27$ & $0.400 \pm 0.03$ \\
Tectona grandis & 43 & 570 & $16.74 \pm 2.10$ & $0.322 \pm 0.04$ \\
Natural forest & - & 556 & $20.05 \pm 0.47$ & $0.393 \pm 0.01$ \\
\hline
\end{tabular}

Abbreviation: N - number of trees; TTCS - total tree carbon stock; MTCS - mean individual tree carbon stock

\section{Soil Carbon Stock in J4 Section of OFR}

The estimates of the soil carbon stock for the five forest-types in J4 Section of Omo Forest Reserve are shown in table 5 . At the depth of $0-15 \mathrm{~cm}$, natural forest has the highest amount of 0.9669 ton/ha, followed by Pinus caribaea (0.6983 ton/ha), Tectona grandis (0.5417 tons/ha), Gmelina arborea (0.2708 ton/ha), and Nauclea diderrichii plantation has the least with 0.2255 ton/ha. Similarly, at soil depth of $15-30 \mathrm{~cm}$, natural forest was highest in terms of carbon stock with 0.9669 ton/ha, followed by Pinus caribaea (0.6089 ton/ha), Tectona grandis $(0.4696$ ton/ha), Nauclea diderrichii (0.3932 ton/ha). However, Gmelina arborea had the least at this soil depth with 0.3274 ton/ha.

Table 5: Estimates of Soil Carbon Stock in the Five Forest-types

\begin{tabular}{lccc}
\hline Forest type & $\begin{array}{c}\text { Soil carbon } \\
\text { 0-15 cm depth } \\
\text { (tons/ha) }\end{array}$ & $\begin{array}{c}\text { Soil carbon } \\
\text { 15-30 cm depth } \\
\text { (tons/ha) }\end{array}$ & $\begin{array}{c}\text { Total soil carbon } \\
\text { (tons /ha) }\end{array}$ \\
\hline Gmelina arborea & 0.2708 & 0.3274 & 0.5982 \\
Pinus caribaea & 0.6983 & 0.6089 & 1.3072 \\
Nauclea diderrichi & 0.2255 & 0.3932 & 0.6187 \\
Tectona grandis & 0.5417 & 0.4696 & 1.0113 \\
Natural forest & 0.9669 & 0.9669 & 1.0113 \\
\hline
\end{tabular}

\section{Total Carbon Stock in J4 Section of OFR}

The estimates of the total organic carbon in the five forest-types in J4 Section of Omo Forest Reserve are presented in table 6. The result revealed that Pinus caribaea plantation sequestered the highest amount of carbon among all the forest-types with an estimate of $35.78 \pm$ 2.73 tons/ha. This is followed by natural forest (21.98 \pm 2.38 tons/ha) and Gmelina arborea (18.96 \pm 1.82 tons/ha). The Nauclea diderrichii plantation sequestered the least amount of carbon with $17.36 \pm 1.87$ tons/ha. The result further revealed that Pinus caribaea absorbed 131.31士 10.02 tons/ha of $\mathrm{CO}_{2}$ (Table 6). This is followed by natural forest ( $80.67 \pm 8.7$ tons/ha), Gmelina arborea (69.58 \pm 6.7 tons/ha), with Nauclea diderrichii having the least $\mathrm{CO}_{2}$-capturing capacity (63.71 \pm 6.9 tons/has of atmospheric carbon). 
Table 6: Estimated Total Carbon Stocks Per Hectares of the Forest types

\begin{tabular}{lccc}
\hline Forest types & Age $(\mathbf{y r})$ & TCS (tons/ha) & CO $_{2}$ (tons/ha) \\
\hline Gmelina arborea & 35 & $18.96 \pm 1.82$ & $69.58 \pm 6.7$ \\
Pinus caribaea & 23 & $35.78 \pm 2.73$ & $131.31 \pm 10.02$ \\
Nauclea diderrichii & 43 & $17.36 \pm 1.87$ & $63.71 \pm 6.9$ \\
Tectona grandis & 43 & $17.75 \pm 2.13$ & $65.14 \pm 7.8$ \\
Natural forest & - & $21.98 \pm 2.38$ & $80.67 \pm 8.7$ \\
Mean & & $22.37 \pm 7.71$ & $82.1 \pm 28.3$ \\
\hline
\end{tabular}

\section{Land-cover Classes in the J4 Section of Omo Forest Reserve}

The four land-use/land-cover (LULC) types distinguished in the study area are presented in table 7. They were closed forest, degraded forest, built-up areas and bare land. The spatial extents of land-cover types in the forest reserve between 1991 and 2019 are presented in table 8.

Table 7: Description of the Land Covers

\begin{tabular}{ll}
\hline LULC & \multicolumn{1}{c}{ Description } \\
\hline $\begin{array}{l}\text { Closed-canopy forest } \\
\text { Degraded forest }\end{array}$ & $\begin{array}{l}\text { This is a forest with closed canopy, either natural or forest plantation. } \\
\text { This include forest lands with open canopy, where Taungya farming } \\
\text { (agroforestry) is being practiced with trees of open-canopy cover. }\end{array}$ \\
Built-up area & $\begin{array}{l}\text { An area covered with houses, offices or other building structures, which } \\
\text { decreases during a period of time, and may later increase inintensity over }\end{array}$ \\
& $\begin{array}{l}\text { some period(s). } \\
\text { This is an area of land with no vegetation, or abandoned farmland that } \\
\text { has not been regenerated. }\end{array}$ \\
\hline
\end{tabular}

Abbrevation: LULC - land use/land cover

Table 8: The Spatial Extent of LULC Between 1991 and 2018

\begin{tabular}{lllllcccc}
\hline \multirow{2}{*}{ LULC } & \multicolumn{4}{c}{ Area (ha) } & \multicolumn{4}{c}{ Area (\%) } \\
\cline { 2 - 9 } & 1991 & 2002 & 2014 & 2019 & 1991 & 2002 & 2014 & 2019 \\
\hline Closed forest & 51705.54 & 52297.92 & 44997.57 & 52547.13 & 65.4 & 66.1 & 56.9 & 66.4 \\
Degraded forest & 15892.29 & 12827.88 & 13364.64 & 7275.15 & 20.1 & 16.2 & 16.9 & 9.2 \\
Built-up area & 7154.28 & 10610.73 & 7524.45 & 9290.88 & 9.0 & 13.4 & 9.5 & 11.7 \\
Bare land & 4366.44 & 3381.93 & 13231.71 & 10006.29 & 5.5 & 4.3 & 16.7 & 12.6 \\
Total & 79118.55 & 79118.46 & 79118.37 & 79119.45 & 100 & 100 & 100 & 100 \\
\hline
\end{tabular}

Abbrevation: LULC - land use/land cover

In 1991 (Figure 3), closed-canopy forest occupied 51705.54 ha $(65 \%)$ of the reserved land with the degraded forest covering 15892.29 ha $(20 \%)$. The built-up areas occupied 7154.28 ha $(9 \%)$ at the time with bare land being the least with just 4366.44 ha $(6 \%)$. In 2002, closed-canopy forest increase to 52297.92 ha $(66 \%)$, degraded forest decreased to 12827.88 ha $(16 \%)$. Built-up area, however increased by $5 \%$ to 10610.73 ha (14\% of the land area). Nevertheless, bare-land declined by $2 \%$ due to regeneration and agroforestry interventions in form of Taungya farming to 3381.93 ha, which was $4 \%$ of the total area (Figure 4). In 2014, the closed-canopy forest declined by $11 \%$ of its value in 2002 to 44997.57 ha $(57 \%$ of the total area), degraded forest increased by $13 \%$ of the previous area to 13364.64 ha (i.e $17 \%$ of the area in that year). In the same vein, bare land 
increased by $13 \%$ to 13231.71 ha during this period (Figure 5).

In 2019, however, closed-canopy forest increased by $9 \%$ to 52547.13 ha $(66 \%$ of the area) with degraded forest shrinking by $8 \%$ of the previous value in 2014 to 7275.15 ha resulting from the agroforestry plots closing their canopies, thereby increasing the closed-forest size. Bare land also declined by 4\% within the period (2014 to 2019) to 10006.29 ha (13\% of the area). Built-up area, however, increased by 3\% to 9290.88 ha (Figure 6).

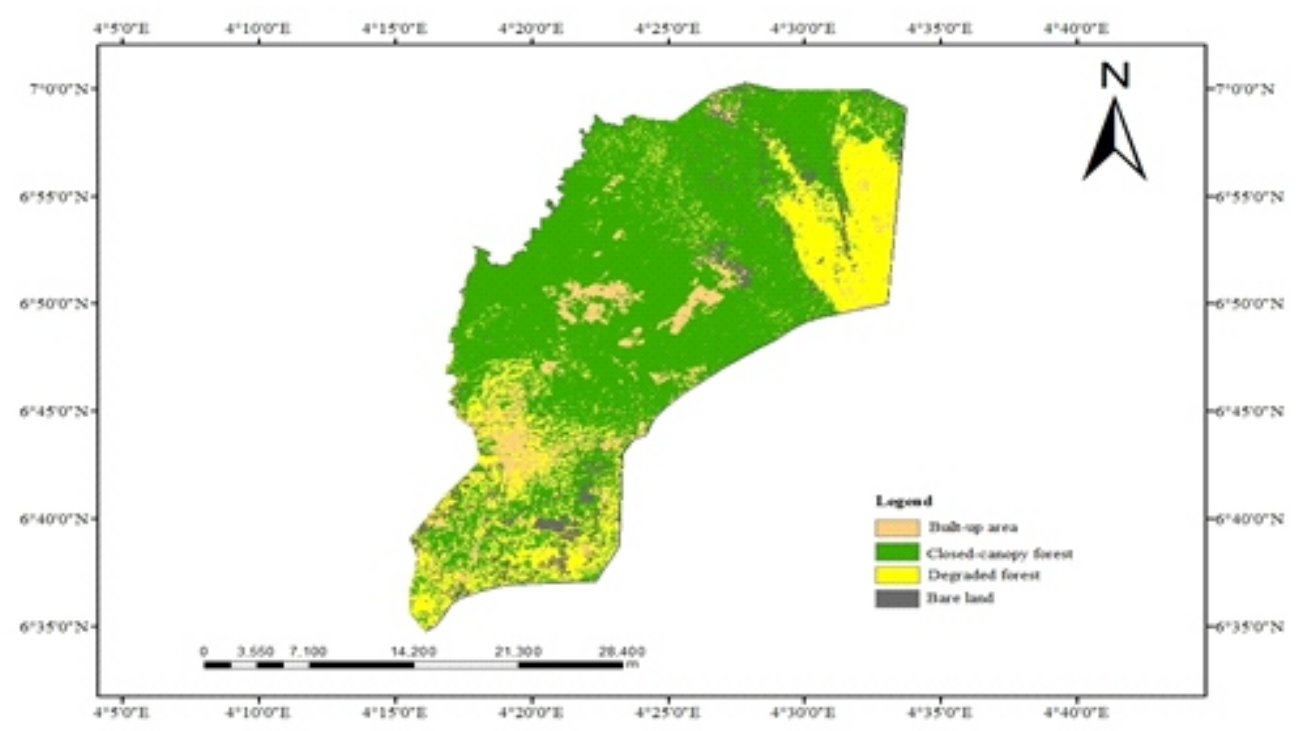

Figure 3: Land-cover Change in J4 Section of OFR in 1991

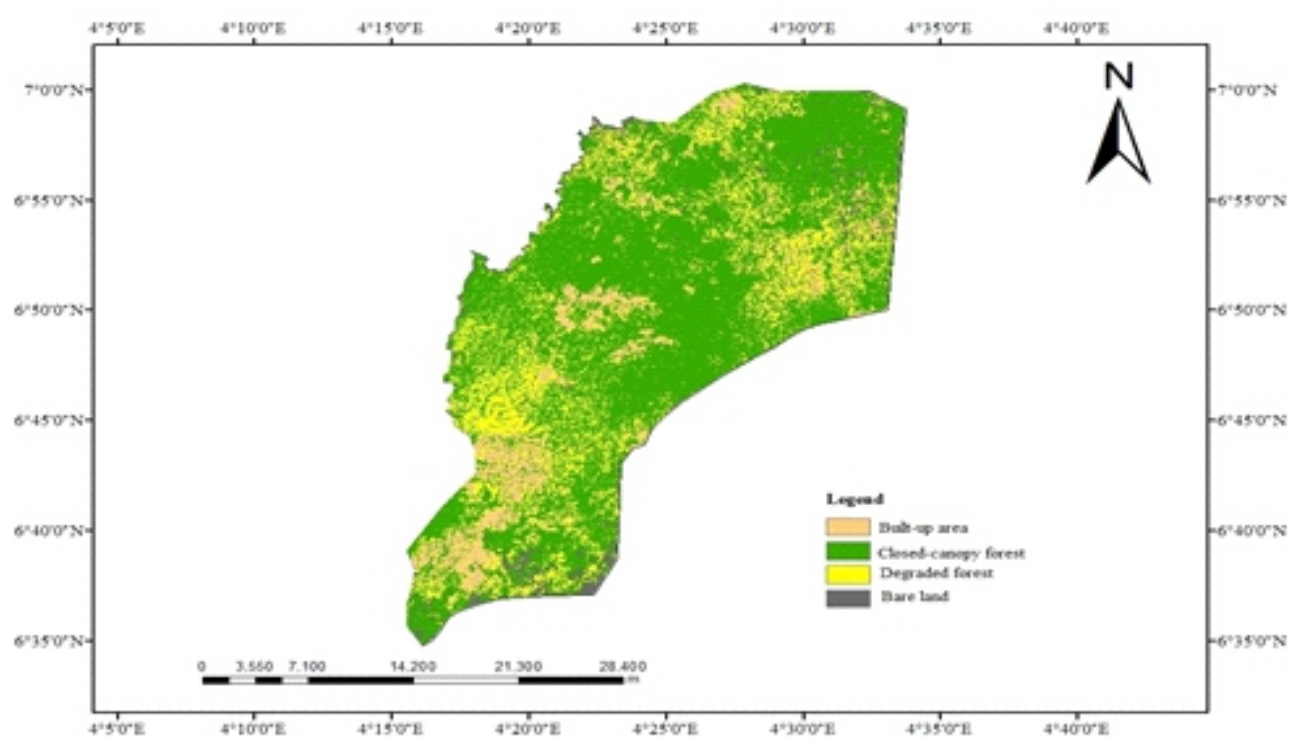

Figure 4: Land-cover Change in J4 Section of OFR in 2002 


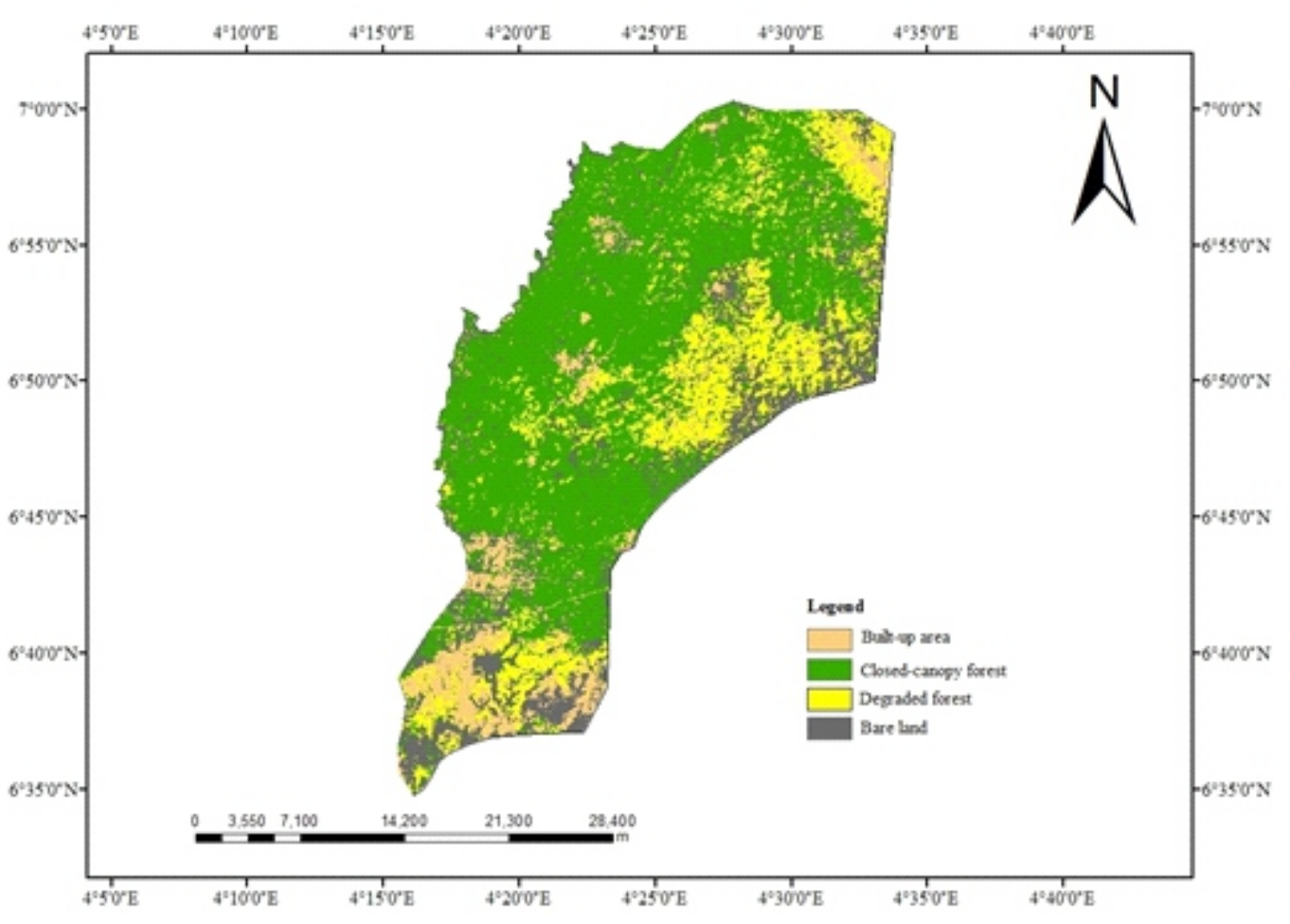

Figure 5: Land-cover Change in J4 Section of OFR in 2014

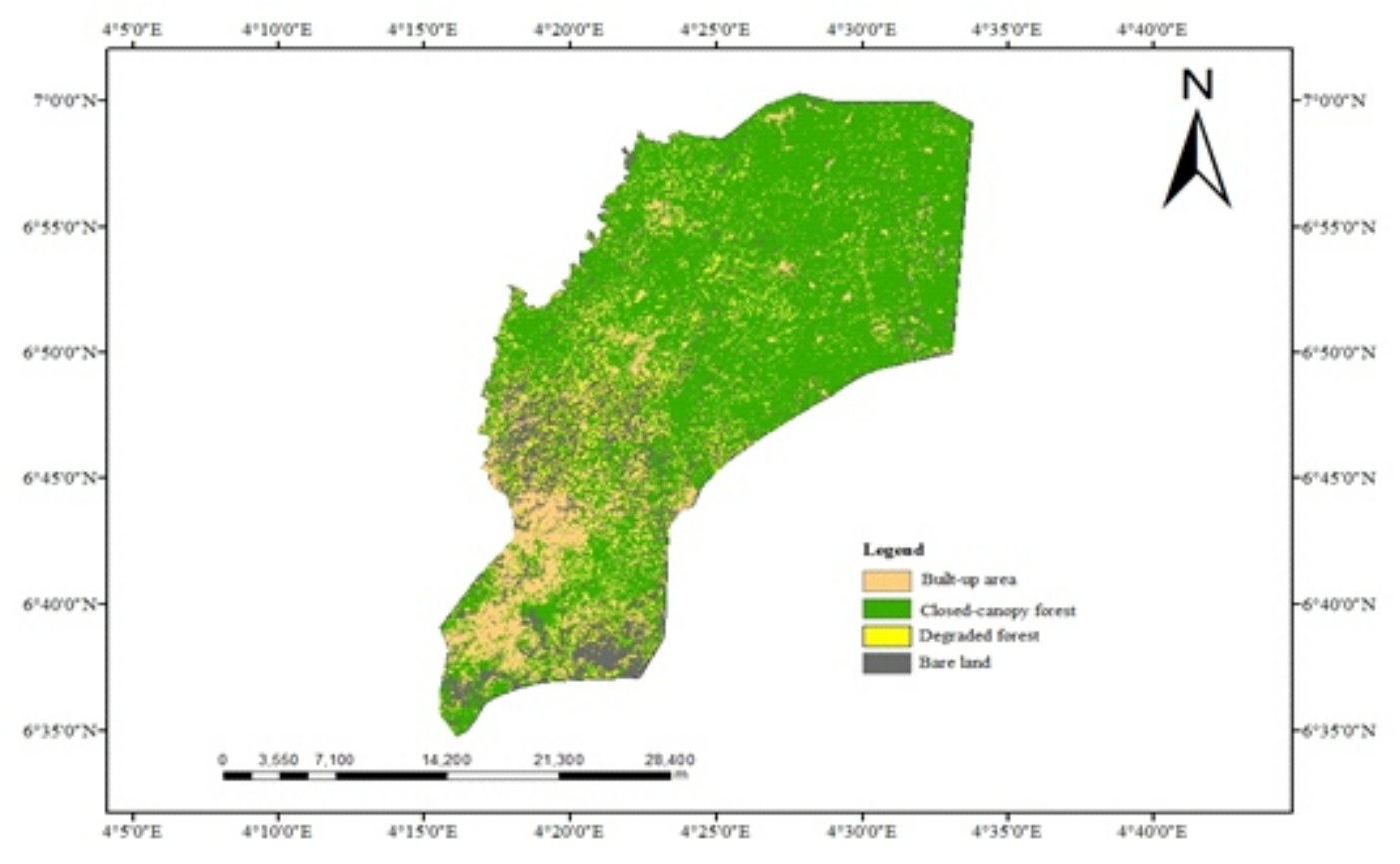

Figure 6: Land-cover Change in J4 Section of OFR in 2019

Land-cover Change Trends Between 1991 and 2019

The trend analysis of the forest reserve revealed a change in size of land covers over the 28-year period (Table 9). Closed-canopy forest increased by $1 \%$ while degraded forest lost about $11 \%$ of its original extent within the period. One per cent of which was added to the closed-canopy forest with about $10 \%$ lost to other forms of conversion like road building and residential areas. 
Table 9: LULC Change Trend Between 1991 and 2019

\begin{tabular}{llllccc}
\hline & \multicolumn{3}{c}{ Change (ha) } & \multicolumn{3}{c}{ \% Change } \\
\cline { 2 - 7 } LULC & $\mathbf{1 9 9 1 - 2 0 0 2}$ & $\mathbf{2 0 0 2 - 2 0 1 4}$ & $\mathbf{2 0 1 4 - 2 0 1 9}$ & $\mathbf{1 9 9 1 - 2 0 0 2}$ & $\mathbf{2 0 0 2 - 2 0 1 4}$ & $\mathbf{2 0 1 4 - 2 0 1 9}$ \\
\hline Built-up area & 3456.45 & -3086.28 & 1766.43 & 4.4 & -3.9 & 2.2 \\
Close Forest & 592.38 & -7300.35 & 7549.56 & 0.7 & -9.2 & 9.5 \\
Degraded forest & -3064.41 & 536.76 & -6089.49 & -3.9 & 0.7 & -7.7 \\
Bare Land & -984.51 & 9849.78 & -3225.42 & -1.2 & 12.4 & -4.1 \\
\hline
\end{tabular}

Abbrevation: LULC - land use/land cover

The result of classification accuracy assessment is presented in table 10. The overall accuracy of the classification was $86.5 \%$. Producer's accuracies ranged between 0.9329 and 0.9716 while user's accuracies were between 0.6976 and 0.9379 . This statistic is more relevant, and measures the classification actual utility in the field (Rwanga and Ndambuki, 2017). The overall Kappa's coefficient obtained for this study was 0.87 .

Table 10: Classification Accuracy Assessment Results

\begin{tabular}{lcccccc}
\hline \multirow{2}{*}{ LULC Classification } & \multicolumn{7}{l}{ Category-wise accuracy statistics } \\
\cline { 2 - 7 } & Specificity & CE & OE & UA & PA & Kappa coefficient \\
\hline Built-up area & 0.9837 & 0.0163 & 0.0015 & 0.6976 & 0.9583 & 0.901 \\
Closed Forest & 0.9735 & 0.0265 & 0.0029 & 0.8723 & 0.9716 & 0.861 \\
Degraded Forest & 0.9537 & 0.0463 & 0.0081 & 0.7951 & 0.9329 & 0.842 \\
Bare Land & 0.9712 & 0.0288 & 0.0029 & 0.9379 & 0.9671 & 0.876 \\
Mean & 0.9705 & 0.02948 & 0.0039 & 0.8257 & 0.9575 & 0.87 \\
\hline
\end{tabular}

Abbrevation: LULC - land use/land cover ; CE - commission error; OE - omission error; UA - user's accuracy; PA - producer's accuracy; Overall accuracy $=\mathbf{8 6 . 5} \%$

\section{DISCUSSION}

The results revealed that species differences and stand density significantly influenced the amount of carbon sequestered among the five forest-types with Pinus caribaea plantation having more net total biomass and carbon stock and Nuclea diderrichii plantation sequestering the least amount of carbon in the area. This corroborates Guo et al. (2010), who noted the profound influence of plant density on the accumulation of carbon in any forest. However, age does not seem to have much effect on biomass and carbon stock among species as 23-year-old Pinus caribaea sequestered almost twice the amount sequestered by 35-year-old Gmelina arborea, and more than double of the estimates for 43-year-old Nauclea diderrichii and Tectona grandis plantations as well as the tree-level carbon stocks. The four plantation species were planted at the same spacing of $2.5 \times 2.5 \mathrm{~m}$, and unthinned.
Nevertheless, within-species variations at later growth stages are possible since same species tends to accumulate more biomass and carbon stocks.

As reported by Kohl et al. (2017), some tropical tree species may accumulate up to 50 percent of their final carbon stock in the last quarter of their lifetime. This is also in consonance with the finding of Idiege et al. (2013), who reported higher biomass accumulation for Gmelina arborea at later growth stages. Whereas, this may not be so for pine species, whose rates of carbon stock accumulation were better at early stage of development (Zhang et al., 2019).

However, it has been noted that decline in forest biomass is attributed to the mortality or loss of large trees within the stand, which must have caused changes in stand density and structure. In effect, it did not imply that carbon accumulation 
decline has to do with the individual tree growth, or stand structure but a reduction in stand density due to mortality (Xu et al., 2012). This impacted the total forest biomass and carbon stock negatively. In the present study, three stand density parameters, which affected biomass and carbon stock accumulations and distributions were trees, basal area and stem volume per hectare. Although it has been reported that litters and biomass accumulations in pine plantation are expected to be smaller with correspondingly less organic matter (Robert et al., 2002), in the present study, soil carbon stock was highest under pine plantation. It is possible that stand density contributed positively to the amount of litter, and consequently, organic matter. This may also be due to the activities of arbuscular mycorrhiza. According to Okonji et al. (2018), arbuscular mycorrhiza directly improve important soil properties for plant growth, and also contribute remarkably to soil organic matter by increasing microbial population and activities. At lesser density, however, natural forest was richer than Gmelina arborea plantation in terms of soil carbon stock, probably due to richer concentration of tree species with better accumulation of organic matter in natural forest compared to a monoculture plantation of Gmelina arborea.

The result of change detection and forest-cover analysis showed that anthropogenic activities impacted negatively on the forest reserve. However, the closed forest increased between the period by $1 \%$. Azeez et al. (2017) noted great contributions of taungya system of farming to forest regeneration in Oso Forest Reserve of Oyo State. A similar case may have played out in the study area. Izekor and Ajobi (2016) have also noted the importance of taungya farming in enhancing forest regeneration while contributing immensely to the income base of the practicing farmers in Edo State. The finding of this study is also in consonance with the finding of Chamshama et al. (1992), who reported that taungya system impacted tree survival positively. However, taungya farming has been reported to fail in some places in Nigeria for lack of government support and necessary incentives (Ehiagbonare, 2006).
The gain in closed-canopy forest was not commensurable to the loss of degraded or secondary forest to bare land by $10.9 \%$ and builtup areas to the tune of $2.7 \%$ and $7.1 \%$, respectively due to encroachments by local communities around the reserve, who farmed within the forest reserve. The continued farming in the area has left most part of the secondary forest badly degraded and almost non-existent. It appears that as population increases, which were seen in form of increment in number of built structures in the area, the more land was needed, and the more the secondary forest disappeared. Basnyat (2009) noted the negative impacts of demographic changes, especially population growth, wood and housing demands on forest degradation and eventual deforestation. This is in line with the observations by Mmom and Mbee (2013), who noted the negative effects of population growth and infrastural developments on forest extent. Forests, in developing world with high poverty rate, hardly thrive in atmosphere of geometric population increases, as people continued to turn to forests and forest lands for virtually every need.

\section{CONCLUSION}

This study has shown that carbon sequestration in the reserve is dependent upon tree species composition and less-inflenced by ages among the forest-types. However, we found that stand density has great contribution to tree biomass and carbon stock accumulations with direct consequences on soil carbon stock. At the age of 23 years, an individual stem of Pinus caribaea could accumulate $9.5 \%$ more of carbon than a 43 year-old stem of Nauclea diderrichii, 18.6\% more than a 35-year-old stem of Gmelina arborea and $11.1 \%$ more than a 43 -year-old stem of Tectona grandis. There was an addition of about $1 \%$ to the closed-canopy forest within the period probably due to some interventions like afforestation and artificial regeneration. Therefore, further positive interventions to encourage forest regeneration in the reserve is advocated. This would enhance more carbon sink. For future plantation establishments, and when choices are to be made among tree species, especially in the tropics, Pinus caribaea could be a best choice for its ability and potential to sequester more carbon, as observed in 
this study.

The study showed that the use of allometries for carbon stock estimation is adequate, and this presents an opportunity for a non-destructive analysis of carbon in order to prevent further depletion of a badly-degraded ecosystem. Hence, non-destructive approach is advisable at all times, particularly during carbon studies since reliable estimate of carbon stock is possible without cutting down trees. With this in mind, there is urgent need for regeneration and enrichment planting in the reserve for improving the carbon stocks.

\section{REFERENCES}

Adebisi, A.A. 2004. A case study of Garcinia kolanut production-to consumption system in J4 area of Omo Forest Reserve, South-west Nigeria. In: Sunderland, T. and Ndoye, O. (eds): Forest Products, Livelihood and Conservation (Case study of Non-Timber Forest Product Systems), Volume 2 Africa, Pp. 115-132.

Ahmedin, A.M., Bam, S., Siraj, K.T. and Solomon, R.A.J. 2013. Assessment of biomass and carbon sequestration potentials of standing Pongamia pinnata in Andhra University, Visakhapatnam, India. Bioscience Discovery, 4(2): 143-148.

Azeez, T.O, Popoola, L. and Shulamite, I. 2017. An assessment of forest regeneration potential of the taungya system of farming in Oyo State, south-western Nigeria. Southern Forests, 56:1-9.

Basnyat, B. 2009. Impacts of demographic changes on forests and forestry in Asia and the Pacific. Asia-pacific forestry sector outlook study II. Working paper series. Food and Agriculture Organization of the United Nations Regional Office for Asia and the Pacific. Bangkok. 82pp.

Brown, S., Gillespie A. and Lugo A.E. 1989. Biomass estimation methods for tropical forests with applications to forest inventory data. Forest Science, 35: 881902.

Brown, S. 1997. Estimating biomass and biomass change of tropical forests: A primer. A forest resources assessment publication. FAO Forestry Paper 134, 17(203): Pp. 177-186.

Chamshama, S., Monela, G., Person, A. and Sekiete, K. 1992. Sustainability of the taungya system at North Kilimanjaro forest plantation, Tanzania. Agroforestry Systems, 17:1-11.

Cienciala, E., Seufert, G., Blujdea, V., Grassi, G. and Exnerová, Z. 2010. Harmonized methods for assessing carbon sequestration in European Forests European Commission Joint Research Centre Institute for Environment and Sustainability. Luxembourg: Publications Office of the European Union. 328pp.

Ehiagbonare J.E. 2006. Effect of taungya on regeneration of endemic forest tree species in Nigerai: Edo State Nigeria as a case study. Africa Journal of Biotectnology, 5(18): 1608-1611.

Enaruvbe, G.O. and Atedhor, G.O. 2015. Spatial analysis of agricultural landuse change in Asaba, Southern Nigeria. Ife Journal of Science, 17(1):065-074.

FAO 2003. State of the World's Forests. FAO, Rome.100pp.

FAO 2008. Terrestrial Essential Climate Variables for Climate Change Assessment, Mitigation and Adaptation. Food and Agriculture Organization, Rome, Italy. GTOS 52.

FAO 2010. Global Forest Resources Assessment. In: Committee on Forestry and World Forest Week. Rome, October 4, 2010. FAO, Rome.

Folega, F., Zhao, H., Zhang, Y., Wala, K., and Akpagana, K. 2010. Ecological and numerical analysis of plant communities of the most conserved protected area in North-Togo, International Journal of Biodiversity and Conservation, 2: 359369.

Gibbs, H.K., Ruesch, A.S., Achard, F., Clayton, M.K.,Holmgren, P., Ramankutty, N., and Foley, J.A. 2010. Tropical forests were the primary sources of new agri-cultural land in the 1980s and 1990s. Proceedings of the National Academy of Sciences, 107: 16732-16737. 
Guo, J.H., Liu, X.J., Zhang, Y., Shen, J.L., Han, W.X., Zhang, W.F., Christie, P., Goulding, K.W.T., Vitousek, P.M. and Zhang, F.S. 2010. Significant acidification in major Chinese croplands. Science, 327: 10081010.

Haghparast, H., Delbari, A. and Kulkarni, D.K. 2013. Carbon sequestration in Pune University Campus with special reference to Geographical Information System (GIS). Department of Environmental Sciences, Pune University, India and BAIF Development Research Foundation, Pune, India. Annals of Biological Research, 4(4):169-175.

Idiege, D.A., Ijomah, J.U., Amadi, D.C.A. and Lifu, M. 2013. Accumulation and distributionof aboveground biomass in Gmelina aborea age series of acid soil in Ukpon River Forest Reserve of Cross River State Nigeria. IOSR Journal of Environmental Science, Toxicology and Food Technology, 6(1): 27-31.

IPCC 2001. Climate change report of WG1. The scientific basis, and WG2 impacts, adaptation and vulnerability, Cambridge University Press.

Izekor, D., and Ajobi, R. 2016. Imapact of taungya farming on rural farmers in Edo State, Nigeria. Nigeria Journal of Agriculture, Food and Environment, 12(3): 243-248.

Kauffman, J.B. and Donato, D.C. 2012. Protocols for the measurement, monitoring and reporting of structure, biomass and carbon stocks in mangrove forests. Working Paper 86. CIFOR, Bogor, Indonesia.

Kohl, M., Neupane, P.R. and Lotfiomran, N. 2017. The impact of tree age on biomass growth and carbon accumulation capacity: A retrospective analysis using tree ring data of three tropical tree species grown in natural forests of Suriname. PLoS ONE, 12(8):1-17.

Kumar, A. and Sharma, M.P. 2015. Assessment of carbon stocks in forest and its implications on global climate changes. Journal of Material and Environmental Sciences, 6(12): 3548-3564.

Liu, C., Frazier, P., and Kumar, L. 2007.
Comparative assessment of the measures of thematic classification accuracy. Remote Sensing of Environment, 107: 606-616.

Liu, X., Ekoungoulou, R., Loumeto, J.J., Ifo, S.A., Bocko, Y.E. and Koula, F.E. 2014. Evaluation of carbon stocks in above- and below-ground biomass in Central Africa: case study of Lesio-louna tropical rainforest of Congo. Biogeosciences Discussions, 11: 10703-10735.

Lorenz, K. and Lal, R. 2009. Carbon sequestration in forest ecosystems. Springer. California, USA.Pp. 241-260.

Mmom, P.C. and Mbee, D.M. 2013. Population pressure and forest resources depletion in Gele-Gele Forest Reserve of Edo State, Nigeria. International Journal of Physical and Human Geography, 3:31-42.

Ojo, L.O. 2004. The fate of a tropical rainforest in Nigeria: Abeku Sector of Omo F o r e s t Reserve. Global Nest: The International Journal, 6 (2): 116-130.

Okonji, C.J., Sakariyawu, O.S., Okeleye, K.A., Osunbiyi, A.G. and Ajayi, E.O. 2018. Effects of arbuscular mycorrhizal fungal inoculation on soil properties and yield of selected rice varieties. Journal of Agricultural Sciences, 63(2): 153-170.

Ostadhashemi, R., Rostami, T. and Roehle, H. 2014. Estimation of biomass and carbon storage of tree plantations in northern Iran. Journal of Forest Science, 9: 363-371.

PeRie, C. and Ouimet, R. 2008. Organic carbon, organic matter and bulk density relationships in Boreal forest soils. Canadian Journal of Soil Science, 88(3): 315-325.

Ponce-Hernandez, R. 2004. Assessing carbon stocks and modelling win-win scenarios of carbon sequestration through land-use changes. Food and Agriculture Organization of the United Nations, Rome

Robert, G.M., Hofstede, J.P. Groenendijk, R.C. Jan, C.F, and Jan, S. 2002. Impact of pine plantations on soils and vegetation in the Ecuadorian High Andes. Mountain Research and Development, 22(2): 159- 
167.

Rwanga, S.S. and Ndambuki, J.M. 2017. Accuracy assessment of land use/land cover classification using remote sensing and GIS. International Journal of Geosciences, 8: 611-622.

Zhang, X., Zhang, X., Han, H., Shi, Z. and Yang, X. 2019. Biomass accumulation and carbon sequestration in an age-sequence of Mongolian pine plantations in Horqin sandy land, China. Forest, 10 (197):1-18.

Xu, C., Turnbull, M.H., Tissue, D.T. Lewis, J.D., Carson, R., Schuster, W.S.F., Whitehead, D., Walcroft, A.S., Li, J. and Griffin, K.L. 2012. Age-related decline of stand biomass accumulation is primarily due to mortality and not to reduction in NPP associated with individual tree physiology, tree growth or stand structure in a
Quercus-dominated forest. Journal of Ecology, 100: 428-440.

Ullah, M.R. and Amin, M. 2012. Above- and below-ground carbon stock estimation in a natural forest of Bangladesh. Journal of Forest Science, 58: 372-379.

Vashum, K.T. and Jayakumar, S. 2012. Methods to estimate above-ground biomass and carbon stock in natural forests: A review. Journal of Ecosystem and Ecography, 2: 116-120.

Watson, R.T., Noble, I.R., Bolin, B., Ravindranath, N.H., Verardo, D.J., and Donken, D.J. 2000. Land use, land-use change and forestry. Special report of the Intergovernmental Panel on Climate Change (IPCC), Cambridge University Press, Cambridge, USA. 375pp. 